\title{
RELATIONSHIP BETWEEN IBN KHALDUN'S URBAN PLANNING AND THE PLANS OF THE LOCAL AUTHORITY OF BANDAR BARU BANGI
}

Received July 30th, 2021 | Accepted November 19th, 2021 | Available online December 15th, 2021 |

DOI http://dx. doi. org/10.18860/jia.v6i4.13045

Ismar Minang Satotoy Usman

Department of Architecture,

Faculty of Engineering and Built Environment, Universiti Kebangsaan Malaysia

Malaysia

ismar.ms@ukm.edu.my

\section{Nor Syafinaz Md Safar}

Institut Hadhari,

Universiti Kebangsaan Malaysia

Malaysia

\section{Shamsul Azhar Yahya}

Institut Hadhari,

Universiti Kebangsaan Malaysia

Malaysia

\section{Nangkula Utaberta}

Architecture Department,

Faculty of Civil Engineering and Built Environment

Universiti Tun Hussein Onn Malaysia

Malaysia

\section{Amirul Hakim}

Department of Architecture

Faculty of Built Environment

Universiti Malaya

Malaysia

\begin{abstract}
Urban planning is a combination of two important factors: arts and science. It is used to facilitate the economic, social, political and physical changes of an area, including the selection of urban location, shape, and impact of urban planning. Comprehensive planning realizes the needs of the population with strong support from the local political authority. This study analyses the relationship between Ibn Khaldun's urban planning principles to Bandar Baru Bangi's urban planning and physical development. This study uses the content analysis method from the primary source of Ibn Khaldun's "Mukadimah" and government documents; the Rancangan Tempatan Majlis Perbandaran Kajang (Pengubahan 4) 2020 [RT MPKj (P4) 2020]. It is the official document that discusses the proposal of land use and physical development in the Majlis Perbandaran Kajang (MPKj) area. Special planning guidelines were used to develop Bandar Baru Bangi (BBB) as "Bandar IImu" (Knowledge City) and also part of the Multimedia Super Corridor (MSC) project. Urban planning by Ibn Khaldun and the Cyber Centre Planning Guidelines by MPKj in RT MPKj (P4) 2020 have similarities and differences. It is because of the wide time interval between both (years 1344 and 2011). The impact of technology provides different views and plans in both. However, urban planning goals and objectives remain the same: to provide comfort, convenience, and peace for people to conduct daily routines while improving security and progress.
\end{abstract}

\section{KEYWORDS:}

Urban Planning, mukadimah, Physical Development

\section{INTRODUCTION}

Urban planning and the existence of human civilization are said to have been developed concurrently [1]. Urban planning aims to identify development problems faced in an area and find suitable and holistic solutions. At the same time, proper planning can oversee the level of development in an area. Development control involves physical planning, land use, and environmental supervision for the needs of people. Planning is also a combination of the art and science of regulating land use and building positions to improve economic status, create comfort, and maintain peace. Thus, there is a link between providing facilities with an integrated layout plan into a comfortable environment.

Ibn Khaldun is an Islamic philosopher who was born in $1332 \mathrm{AD}$. The most common name used in Ibn Khaldun's writings is 'Abd al-Rahman bin Muhammad bin Muhammad bin Muhammad bin al-Hasan ibn Muhammad ibn Jabir ibn Muhammad bin Ibrahim bin' Abd al-Rahman ibn Khaldun. His pen name is Ibn Khaldun. He was born in Tunisia, but his ancestors were from Hadramaut, Yemen. He travelled a lot around North Africa, Eastern Europe and the Arabian Peninsula for various purposes and objectives, but most importantly, for knowledge and earning a living. He died in Egypt in 1406 AD[2].

Ibn Khaldun was a historian, sociologist and, most notably and universally acknowledged, the founder of the social science discipline. In his famous book, "Mukadimah," he outlined the principles of city planning. He also analyzed the factors of the beginning and fall of civilizations and culture with the Muslim civilization and its culture as his model [3][4]. Furthermore, Ibn Khaldun argued that psychological, economic, environmental and social factors contribute to the advancement of human civilization. He proclaimed that sovereignty was the only determinant for people to live peacefully. He also argued that only with a city or country, and not desert-living and such, could a civilization exist. Lastly, a good and wise government was also imperative for people to live and continue their existence [2], [4].

Ibn Khaldun's idea of urban planning could be 
seen through his experience functioning as a civil servant and politician. He dutifully observed the ups and downs of a kingdom, the civilization and the role of government. For him, a city or a kingdom couldn't be developed without the existence of organized people whose functions was to develop a city [5]-[7].

According to him, building and urban planning was a characteristic of sedentary life after denizens had acquired a certain luxurious standard of living and peace. Such a lifestyle could be achieved after abandoning a life-changing culture (badw). Therefore, peaceful existence could provide a safe and intelligent mindset for self-improvement. All of these would manifest in the formation of a city and the community in it [5]-[7].

Bandar Baru Bangi is a suburban city. However, it lacks important urban elements [8] [9]. It constitutes the problem this research would like to discuss. The physical appearance and development of a city are very important considerations for an inhabitant. As a Knowledge City, BBB should have a very strong and powerful identity for residents to see and feel. Unfortunately, the surroundings of BBB often look shabby and dirty, giving an appearance of a city that is not well managed [8]. The local authority has failed to develop BBB into a Knowledge City even though there are spelt out guidelines for this special area.

This study analyses the relationship between Ibn Khaldun's urban planning principles to Bandar Baru Bangi's urban planning and physical development. The area was first developed in 1974 after the State Development Economic Corporation [Perbadanan Kemajuan Negeri Selangor (PKNS)] acquired the land in stages from 1972 to 1978 . The first stage began with Section 1: it involved the construction of low-cost, medium-sized and luxury houses, totalling 200 units. The main construction activity ended in 2007, with the building of 11,040 residential units, 308 units of shops, 43 units of factories and an office complex [8].

Bandar Baru Bangi, the second-largest city in Selangor after Shah Alam, is based on an integrated plan accommodating 60,000 residents with commercial, industrial, business, training, recreational and educational features. Thus, it answered the prime minister's call, Tun Abdul Razak, who desired to change the Malaysian society and economy from agricultural to industrial [10].

Because BBB is located within the administration of the Kajang Municipal Council [Majlis Perbandaran Kajang (MPKj)], it is the Council's responsibility to safeguard, preserve, manage and develop BBB into a Knowledge City as planned. MPKj has to develop BBB using guidelines provided by the Town and Country Planning Department (JPBD) in the latest Local Plan known as RT MPKj 2020.

BBB is classified as a Knowledge City. It falls under a specific action plan called the Special Area Plan [Rancangan Kawasan Khas (RKK)]. The preparation of this RKK aims to promote, rebuild, refine, preserve, and manage the area. The latest amendment to the Town and Country Planning Act, Act 172, Act A 1129, has provided for the preparation of the Special Area Plan (RKK) specified in section 16B (1) (2) (3). The plan is locally and specially designed for areas with interest to the Local Planning Authority [Pihak Berkuasa Perancangan Tempatan (PBPT)]. The preparation of the RKK also allows PBPT to accelerate planning action in an area for developing, promoting, redefining, maintaining and managing the area. In addition, RKK also has the power of Local Plans [11]

RT MPKj 2020 is an official document that translates policies and proposals in the State Structure Plan (RSN) to a more detailed physical form according to plots until 2020. This document consists of land use in written statements and is supported by subject, insertion, and land use classes. It also describes all proposed land and physical development proposals for the development and use of land in the MPKj area.

The preparation of this RT document is the third stage of the country's land and physical planning system, as provided under the Town and Country Planning Act 1976, after the National Physical Plan [Rancangan Fizikal Negara (RFN)] and the State Structure Plan [Rancangan Struktur Negara (RSN)]. The goal of RT MPKj 2020 is to make the Kajang district a quality living environment [12].

There are five functions of the RT:

- $\quad$ First, to translate the basics of the State Structure Plan (RSN);

- $\quad$ Second, to act as a guideline for the physical development of districts and related PBPT through a land-use map;

- Third, to provide guidelines for development control;

- $\quad$ Fourth, to identify major districts; and

- $\quad$ Fifth, to identify district projects and provide implementation guidelines.

To enable the development of the study area to be in line with national development, each RT will be reviewed after several years and replaced with a new RT called RT MPKj (Replacement). At the same time, the conversion process is also made to record the current development changes in the area.

MPKj has set up a special guideline in RT MPKj 2020 to develop BBB as a Knowledge City while supporting MPKj's development efforts as a cyber centre. In line with this, the proposal for the development of the Multimedia Super Corridor (MSC) in Putrajaya-Sepang-Bangi can be complemented by the completion of the Bandar Baru Bangi Conurbation [13], [14]. Thus, MPKj has provided specific guidelines for BBB to control local development, trade and economic activities, as well as building design and guidelines.

Ibn Khaldun prescribed urban planning guidelines during his time. His principles of urban planning reflected the life of that time. Zaid [15], however, believed that Ibn Khaldun's urban planning principles remain relevant today. Ibn Khaldun's urban planning principles emphasized three important factors: security, comfort and peace. Ibn Khaldun was also a 
pioneer in historiography and philosophy. He was well acquainted with the concept of civilization. He argued for the security/defence principle so that civilization could be preserved and last longer. Hence, it was important for a city or kingdom to be built in ways for the city to survive and thrive.

For a city to survive and thrive, anything that threatens a city's well-being should be avoided, whether the threat was to the environment or committed by humans, and whether the threat has long-term or short-term effects. Therefore, the construction of a city needed to be carried out carefully, especially from the perspective of site selection, urban planning, and site measurement. After all these aspects were implemented according to agreed plans, and all facilities were included, the city or kingdom was safe to live in [16].

Mawlay Idris al-Azhari (789 AD) once recited this prayer to ALLAH SWT during the Fez City opening in North Africa [17]:

Oh, my Lord, You know that I don't intend by building this city to gain pride or to show off, nor do I intend hypocrisy or reputation or arrogance, but I want You to be worshipped in it; Your laws, limits, and the principles of Your Qur'an and the guidance of Your Prophet to be upheld in it, as long as this world exists. Almighty, help its dwellers to do righteousness and guide them to fulfil that. Almighty, prevent from them the evil of their enemies, bestow Your bounties upon them and protect them from the sword of evil. You can do all things.

Although intangible, Ibn Khaldun believed in the sanctity of religion. He espoused for a population of a city or kingdom to follow the Sharia for peace and blessings.

\section{METHODOLOGY}

This research used content analysis to analyze the "Mukadimah" (in the city planning subtopic only) and the latest plan called RT MPKj (Penggubahan 4) 2020, which was used in Bandar Baru Bangi development from 2011 until 2020. The analysis then would compare these two reference documents since the objective of this paper was to analyze the relationship between urban planning by Ibn Khaldun and the urban planning and physical development of BBB from the RT. The planning and physical development of BBB referred to was the RT MPKj (P4) 2020. The schedule (Table 1 ) was provided below to compare the differences and similarities.

\section{RESULT DAN DISCUSSION}

The Cyber Centre Planning Guidelines in RT MPK (P4) 2020 contain the functions of Entrance, Focal Points, and Landmarks functions. These three municipal elements serve as markers or signage for a city to be easily identifiable by visitors and become a landmark for the area and its identity. However, it is opposed to Ibn Khaldun's view of this element. He thought that landmark construction such as monuments and large buildings could only be built after a governor had furnished the needs of the people. In addition, Ibn Khaldun was also very concerned about the city's security factor. Hence, he seemed to want to "hide" the city's position like a city built on a hill, in a forest, a high place, a wet area and a bridge to be safe from enemy threats. At the same time, he also emphasized the effort to trade through sea routes as one of the elements to generate the country's economy.

Through site planning, RT MPKj (P4) 2020 suggested that planning be tailored to the topography to minimize the impact of cut and fill. It is because cutting involves deforestation and hill hollowing, disturbing the natural ecosystem and animal habitat. The RT also proposed the beautiful city concept to strengthen the relationship between humans and the environment. This principle concerns the cleanliness and keeping flora and fauna intact. Ibn Khaldun also wrote about cleanliness and the natural beauty of an environment but from different aspects. He proposed the treatment of urban atmosphere from air pollution so that air entering the urban area was clean and fresh without being contaminated with dirt and dust. According to him, polluted air could spread diseases and harm people. Clean water sources should also be well maintained so that no pollution occurs. Winds blowing across a contaminated water source could bring about a bad smell to the city. He also proposed the location of clean water sources close to the city for residents' comfort.

Ibn Khaldun advanced the idea of planning on food resources. Two out of seven of his urban planning principles focused on the importance of food resources to residents, livestock and animals used for rides. According to him, good pastures were essential for breeding livestock: for milk, meat and transport. For him, management and maintenance became easier if the location of the meadow was close to the population. Additionally, he also suggested creating open spaces for planting crops like wheat. As with livestock, the location of this farm should be close to the people for quick access and procurement.

In planning the Cyber Centre Planning Guidelines in RT MPKj (P4) 2020, there is no specific clause discussing food resource planning as found in Ibn Khaldun's "Mukadimah." However, there are five directions on this idea. One of them is to make Malay reserve land a competitive area. MPKj intends to develop surrounding land to generate revenue for residents. Food is an important part of life. Society now has a variety of ways to get food. Today, people have constraints in terms of having land for growing. They have no land and fields to plant grain and rear livestock to meet their needs. Instead, food is easily available in supermarkets in the business district provided by the PBT. As a result, many commercial and business development projects were introduced to 
meet the basic needs of the local community. In RT MPKj (P4) 2020, it is recommended that business and commercial areas employ the garden city centre concept with attractive landscape and ample parking space. Moreover, the continuity of pedestrian walkways and green areas will make it easy for people to reach their desired destination. Thus, comfort is attained for users.

Emphasis on building material resources such as wood was also a consideration of Ibn Khaldun because timber was one of the most important building materials during his time. Ibn Khaldun suggested that the city should be closer to the forest to make it easier for timber-related work and to get wood supplies. At that time, timber was the main raw material for building apart from rock, soil and mud. Wood was also fuel for domestic needs: for cooking, heating and other combustion requirements. Furthermore, timber was used for art and furniture. It was also a vital resource that created employment.

Similarly, the MPKj Development Centre stipulates zones capable of managing a productive, stable, and competitive local economic structures. These zones generate employment opportunities for local residence and produce skilled workers. Thus, the Centre manages growth and urban development efficiently in this way.

Ibn Khaldun's thoughts were always forward. He advised the city or kingdom to be close to the sea to facilitate the importation and exportation activities through waterways. These activities were capable of generating revenues, financial resources and were bulwarks of the local economy. He was aware that not all places have this advantage. At the same time, security in waterways ought to be present.

Bandar Baru Bangi is close to an important development nexus, i.e., Putrajaya, Cyberjaya and Kuala Lumpur International Airport (KLIA). This golden area is vibrant with big infrastructure development and mega projects. The MPKj area is expected to receive an overflow of development considering its proximity. In addition, the existence of multiple highways around BBB facilitates the ability of any party to travel into the city. As BBB is located close to the airport, trading and export activities could be carried out as suggested by Ibn Khaldun but using airways.

Ibn Khaldun did not discuss building needs in his urban planning, but mentioned them in other subtopics in the same chapter in "Mukadimah." He noted that only strong sovereignty would be able to build big cities and monuments. He added that significant monuments were not developed in the span of one dynasty. He further noted that only a genuinely stable and strong government had this capability. However, many dynasties desired to build big buildings. He said, "... such a repetition of such a force is needed in a continuous time until the building is completed. A king started it and the second and third king extended the effort,". Ibn Khaldun argued that large buildings and monuments were not built during the early stage of urban life but after the city had a stable and strong position. It means that if the city government does not pay attention to administrating the city, it is less likely to build such buildings.

RT MPKj (P4) 2020 guides buildings in building design, building scale, building façade, and building or residential area displacement. Contrary to Ibn Khaldun's views, present-day development is comprehensive. Developing buildings such as shop lots, commercial buildings and monuments are among the important aspects of urban planning. The design of a building is from the domination point of the building so that the public can clearly and easily understand the design of the administrative and public buildings. In addition, modern-themed design concepts and intelligent building designs are encouraged but at the same time need to take into account facilitation for people with disabillity. The proposed building scale should be in line with the scale of the surrounding development. In addition, it should promote intelligent building features especially in urban areas.

The façade is required to have a meaningful design and give a certain value to give a positive first impression to users. A positive first response is very important to attract the attention of visitors and pique their interest. The appropriate elements applied in the facade design of a building include having openings to allow natural light and air into the building; using attractive colours that match the surroundings; applying shape, size and height of the facade in accordance with the building and the building theme; and using building materials to suit current requirements.

Safe distance between buildings and airspace to provide comfort and relief to building density are important considerations in today's building. Additionally, displacement of buildings to allow inclusion of sunlight on building intersections are equally important. This is in line with the hadith of the Prophet (peace and blessings of Allah be upon him) which means, "And do not exalt the building to prevent the wind from entering its house (your neighbour)". 
Table 1: Comparison of Ibn Khaldun's urban planning principles and MPKj's RT MPKj (P4) 2020 Cyber Centre Planning Guidelines

Ibn Khaldun's Urban Planning Principles
All houses in the city should be situated inside a protective wall.
The city is recommended to be strategically positioned in an
"inaccessible" place, either upon a rugged hill so that any access
to it can be easily manipulated, subject to the prevailing
circumstances, or surrounded by water so that it can be reached
only by crossing some sort of bridge.

In connection with the protection of towns against harm that might arise from atmospheric phenomena, one should ensure that the air where the town is (to be situated) is good, in order to be safe from disease. When the air is stagnant and bad, or close to corrupt waters or putrid pools or swamps, it is speedily affected by putrescence as the result of being near these things, and it is unavoidable that (all) living beings that are there will speedily be affected by disease. Towns where no attention is paid to good air, have, as a rule, many diseases. When the wind gets into (the putrid air), and disperses it left and right, the effect of putrescence is lessened, and the occurrence of illness among living beings decreases correspondingly.

The city must be built close to a stream or even a stream of clean and flowing water. The presence of water in general provide comfort for the residents of the city.

\section{Cyber Center (RT MPKj (P4) 2020) Planning Guidelines}

Site Planning

1. Planning tailored to the topography is preferred to minimize the impact of cut and fill.

2. The concept of beautiful city should be implemented leading to the strengthening of relationship between humans and the environment. Planning principles that need to be emphasized are cleanliness and beauty.

Fabrication of Urban Fabrics

1. The original structure and original circulation system must be maintained.

2. Elements of a city are boulevard development, landmarks such as clock tower or fountain, and iconic buildings.

3. Business and trade areas are proposed for the concept of 'garden city centre', which has an attractive landscaped area, and adequate parking space as a focal area of the city.

4. Provision of pedestrian paths and green areas that are sustainable with the public's focus areas.

\section{Building Design}

1. The domination of administrative buildings and public buildings should be clear in terms of design and architecture to distinguish their interests from the public.

2. Design of modern buildings characterized by intelligent buildings is encouraged.

3. The design of the building should also consider the facilitation aspects for person with disability.

Good pasture for livestock. Every resident must have livestock for breeding and for milk, and to be ridden. If the pasture is near and good, it will make their lives easier, because they will have difficulty in managing them when the pastures are far away.

1. Entrance - Preparation of structural and landscape gate elements should be provided in the main trading area or main entrance to the city centre to indicate identity and sense of welcoming to visitors.

2. Focus Point - Focal Point consisting of building structure and planting of trees or gardens promoted at the end of the road to increase vista and municipal quality.

3. Landmark - The landmark element must be provided at least one in a city, either in the form of a building or monument. Construction of landmarks in strategic places comprising structures and buildings is encouraged to identify the area and orientation of the area residents.

The existence of open grounds can be used for allotments. Grains are a basic source of food. When the fields are nearby, the seeds can be obtained easily and quickly.

Building Scale

1. The proposed building should be suitable in terms of scale with the development of the surroundings.

2. Congruent building scales are encouraged to promote intelligent building features, especially in downtown areas.

3. The construction project should focus on a balanced design and appropriate size between buildings and surrounding areas.

The city is adjacent to a forest for the supply of fuel and building materials.

Building facade

1. The facade design of a building has certain meanings and values that allow users a first impression on the image of a city. The positive first response is necessary to attract visitors to the place or area of the city.

2. Design on the facade of the building, whether new or old, need to follow such elements such as:

a. Opening

b. Colour

c. Shape

d. Building material

e. Façade size

f. Height

The city is close to the sea to facilitate the exportation and importation of goods from distant countries.

Building Shrubs / Coaching Areas

1. 1. The residential area of a building is according to the suitability of the building site or $60 \%$ of the area used for building construction.

2. 2. Criteria to determine the displacement:

a. Security Distance

b. Airspace

c. 'Natural Lighting'

d. Comfort 


\section{CONCLUSION}

Urban planning by Ibn Khaldun prioritized the most important factors of human life: security, safety, comfort. This is in line with the importance of safeguarding the sharia maqasid, namely, maintaining religion, soul, mind, property, and heredity: security, safety, comfort. For him, safety was his primary focus in building a city and civilization. To meet the needs for food, he recommended adjacent open spaces for planting. In addition, other sources of food such as meat and milk were obtained from livestock. Grazing fields should be close for easy management. He also paid attention to the cleanliness of the air and water sources. If not managed well, it could cause the spread of infectious diseases. Additionally, for good and safe urban construction, timber resources should be near to save transport costs and for easy supervision. Ibn Khaldun believed that the economy and international relations were important in urban and country development. He proposed for people to develop a city near the sea so that trade and export can be carried out. However, he also noted that a location close to the sea could bring about security issues. Hence, he proposed security measures to counter these risks.

The Cyber Centre Planning Guidelines in RT MPKj (P4) 2020 is a special guide for Bandar Baru Bangi provided by MPKj to develop the city as a Knowledge City. These guidelines are very important to balance it with commercial and industrial needs. Site selection tailored to topography is a priority to reduce cut and fill. Municipal elements like entrances create identity and a sense of welcoming. Landmarks or sign marks orient the area for residents and visitors alike. The most important principles of this guideline are cleanliness and beauty. The beautiful city concept creates a garden city centre with appropriate landscape and pedestrian paths that connect public areas. Building design applications need to be distinguished based on the function and classification of the building. This includes facilities for people with disability. Development at BBB also needs to focus on designs based on its surroundings. Building facades should contain beauty elements to impress visitors. Last but not least, distance between buildings must be suitable to maintain user safety and comfort and to allow air circulation and the inclusion of natural light into the area.

It can be concluded that Ibn Khaldun's urban planning principles and MPKj's RT MPKj (P4) 2020 Cyber Centre Planning Guidelines contain similarities as well as differences. This is because of the significant time gap between both (14th century and 21st century) causing changing needs. The evolving and dynamic development of technology also explains these differences. However, urban planning goals and objectives remain the same, which is to provide safety, security and order for residents to carry out their daily activities. Thus, Ibn Khaldun's urban planning is still relevant and appropriate to be used today but with improvements so that the community remains in line with current technological advances.

\section{REFERENCES}

[1] I. Wahab, Perancangan Bandar Aspek Fizikal dan Kawalan Pembangunan. Kuala Lumpur: Dewan Bahasa dan Pustaka, 1991.

[2] Y. M. Sidani, "Ibn Khaldun of North Africa: an AD 1377 theory of leadership," Journal of Management History, vol. 14, no. 1, pp. 73-86, Jan. 2008, doi: 10.1108/17511340810845499.

[3] S. Omer, City Planning in Ibn Khaldun's Thought. Kuala Lumpur: International Islamic University of Malaysia, 2011.

[4] I. Khaldun, The muqaddimah: an introduction to history-abridged Edition. Princeton University Press, 2015.

[5] A. O. El-Kholei, “Ibn Khaldun's 'ilm al 'umran?]: a model for planning the sustainable city in the Arab region," Archnet-IJAR: International Journal of Architectural Research, vol. 13, no. 2, pp. 276293, Jul. 2019, doi: 10.1108/ARCH-01-2019-0004.

[6] N. S. Md Safar, S. A. Yahya, I. M. S. Usman, and A. H. Ismail, "IBN KHALDUN'S THEORY, PRINCIPLES AND CONCEPTS ON URBAN PLANNING," Journal of Design + Built, vol. 10, no. 1, pp. 1-7, 2017.

[7] D. Chabane, "The structure of 'umran al-'alam of Ibn Khaldun," The Journal of North African Studies, vol. 13, no. 3, pp. 331-349, Sep. 2008, doi: $10.1080 / 13629380701844656$.

[8] S. Abu Bakar, Bangi Bandar Ilmu. Selangor: Sekretariat Bangi Bandar Ilmu, 2011.

[9] N. Tajul Ariffin, Himpunan Penduduk Bandar Baru Bangi. Bangi: Persatuan Penduduk Bandar Baru Bangi, 2014

[10] N. Omar, Himpunan Penduduk Bandar Baru Bangi . Bangi: Persatuan Penduduk Bandar Baru Bangi, 2014.

[11] Jabatan Perancangan Bandar dan Desa Negeri Selangor, "RKK (Rancangan Kawasan Khas)," Jabatan Perancangan Bandar dan Desa Negeri Selangor, 2018. https:// www.jpbdselangor.gov.my/perkhidmatan-j3/ rancangan-pemajuan/rkk-rancangan-kawasankhas.html (accessed Jul. 21, 2018). 
[12] Jabatan Perancangan Bandar dan Desa Negeri Selangor, Rancangan Tempatan Majlis Perbandaran Kajang (Penggantian 1) 2035. 2017.

[13] Jabatan Perancangan Bandar dan Desa Negeri Selangor, Rancangan Tempatan Majlis Perbandaran Kajang (Pengubahan 4) 2020, vol. Jilid 2. 2011.

[14] Jabatan Perancangan Bandar dan Desa Neger Selangor, Rancangan Tempatan Majlis Perbandaran Kajang (Pengubahan 4) 2020, vol. Jilid 1. 2011.

[15] Z. Ahmad, N. Ahmad, and H. Abdullah, "Ibn Khaldun's Principles on Urban Planning A
Contemporary Reading of The Muqaddima," ibn Haldun Çalışmaları Dergisi, vol. 1, no. 2, pp. 315330, May 2016, doi: https://dx.doi.org/10.36657/ ihcd.2016.15.

[16] F. Baali, Society, State and Urbanism: Ibn Khaldun's Sociological Thought. Ney York: State University of New York Press, 1988.

[17] A. A. Sarkawi and A. Abdullah, "Etika Orang Awam dan Pihak Berkuasa Tempatan dalam Sesi Penyertaan Awam," in Perancangan Bandar Dari Perspektif Islam, A. A. Sarkawi and Al. Abdullah, Eds. Kuala Lumpur: Universiti Islam Antarabangsa Malaysia, 2011, pp. 90-109. 